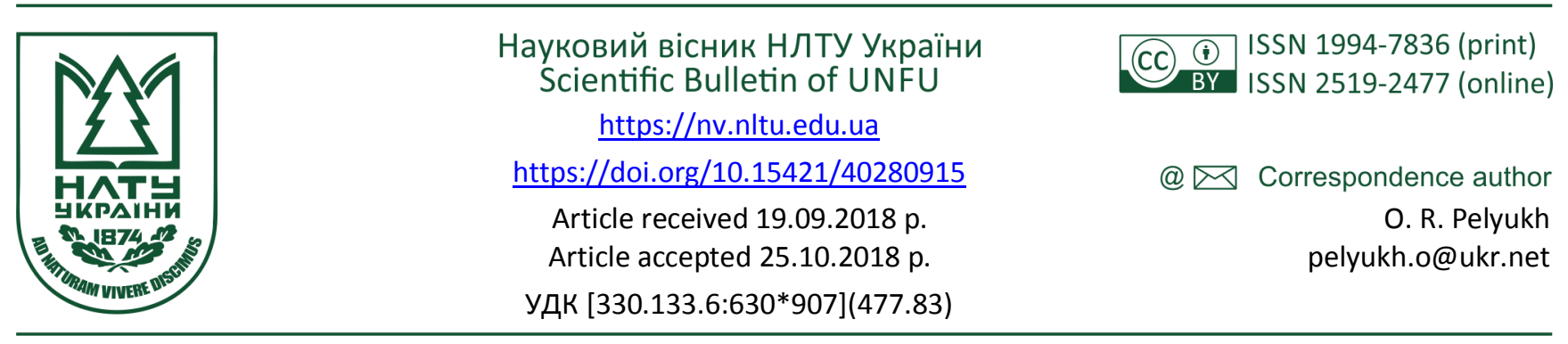

О. Р. Пелюх, Л. Д. Загвойська

Національний лісотехнічний університет України, м. Львів, Украйна

\title{
ДОСЛІДЖЕННЯ УПОДОБАНЬ НАСЕЛЕННЯ ЛЬВІВЩИНИ ЩОДО РЕКРЕАЦІЙНИХ ЛІСІВ МЕТОДОМ ЕКСПЕРИМЕНТУ 3 ВИБОРОМ
}

\begin{abstract}
Зростання попиту на відпочинок у лісах Карпат ставить перед менеджерами лісового господарства нові виклики, пов'язані з необхідністю формування рекреаційно привабливих лісів. В Свропі останніми десятиліттями проведено чимало досліджень щодо суспільного сприйняття рекреаційних лісів, уподобань щодо їхніх характеристик. В Україні таке здійснюють дослідження, однак у них ліси розглядали як узагальнене поняття. Для дослідження вподобань щодо характеристик рекреаційних лісів застосовано один із методів дослідження висловлених переваг- метод експерименту з вибором, теоретичним підгрунтям якого слугують імовірнісна теорія максимізації корисності Д. Макфаддена і "характеристична" теорія поведінки споживача, які сформулювів К. Ланкастером. Моделювання дискретного вибору рекреантом характеристик лісу для відпочинку виконано з використанням багатофакторних регресійних моделей - логіт і пробіт моделей - методом найбільшої правдоподібності з використанням програмного забезпечення BIOGEME 1.8. За результатами аналізу даних з'ясовано, що населення Львівської обл. віддає перевагу мішаним різновіковим лісам, у рекреаційних зонах яких є інформаційно-освітні стенди. Оцінки коефіцієнтів регресії для цих характеристик в обох моделях статистично значущі, додатні і мають найвищі значення. Разом із тим, респонденти не схильні відвідувати ліс, який розташований далеко від місця їх проживання, та ліс, в якому є відмерла деревина. Визначено граничну готовність платити і готовність подолати відстань для відвідування лісу, який відповідає уподобанням респондентів. Обгрунтовано необхідність інтеграції отриманих результатів дослідження у практику прийняття управлінських рішень для зменшення сировинного та розширення рекреаційного використання лісів, відтак формування рекреаційно привабливих лісових ландшафтів і стійких до зміни клімату та антропогенних навантажень деревостанів.
\end{abstract}

Ключові слова: рекреаційні ліси; характеристики лісів; метод експерименту з вибором; уподобання; готовність платити; готовність подолати відстань; логіт і пробіт моделі.

Вступ. В умовах антропоцену, коли дедалі відчутнішим стає вплив людини на перебіг процесів у довкіллі, істотно трансформуються самі екосистеми, попит на їхні послуги i, відповідно, цілі і завдання їх менеджменту. Інноваційний лісовий менеджмент зосереджується на завданнях адаптації лісових екосистем до зміни клімату та повнішого використання їхнього потенціалу для пом'якшення цих зміни, сприяння відновлюваним джерелам енергії, збереження біорізноманіття, а також задоволення соціальних, культурних і матеріальних потреб людини (Zahvoyska \& Melnyk, 2008; UNECE, FAO, 2011). Зазначимо, що за результатами нашого опитування щодо важливості послуг лісових екосистем (ПЛЕ) (Zahvoyska et al., 2017), респонденти визнали найважливішими послуги регулювання і підтримання (середня оцінка 4,23 бали за 5-бальною шкалою), трохи менш важливими - культурні послуги $(3,8)$ і відтак послуги забезпечення $(3,59)$, хоча саме продукування деревини є пріоритетним завданням домінуючої парадигми лісогосподарської діяльності. Тож розуміння $\mathrm{i}$ врахування уподобань рекреантів щодо лісів для відпо-

чинку може принести багато вигід лісогосподарям уже в короткотерміновій перспективі.

Зростання цінності вільного часу та якості дозвілля, найбільш помітне для покоління Міленіум (Budyenko, 2016), відбувається на тлі глобальних процесів урбанізації та індустріалізації великих територій, що зумовлює зростання потреби у відпочинку та відновленні сил на природі. Ліси, як свідчить результати досліджень, проведених у різних країнах Європи (FAO, 1988; Lindhagen, 1996; Roovers et al., 2002), є одним із найпопулярніших місць відпочинку. В Україні, в умовах надмірного навантаження на екосистеми Чорноморського узбережжя після анексії Кримського півострова, зростає попит на відпочинок у лісах Карпат (Nevenchenko, 2015). Зокрема, впродовж 2013-2016 рр. кількість туристів у цьому регіоні збільшилась на $43,63 \%$ (від 103,8 тис. до 149,1 тис. осіб) (Statistics, 2013, 2016). Очікується, що потік туристів буде зростати і надалі, тому посилення естетичної привабливості лісових ландшафтів і покращення рекреаційної інфраструктури у лісових деревостанах є важливим завданням інноваційного

Інформація про авторів:

Пелюх Оксана Романівна, аспірант, кафедра екологічної економіки. Email: pelyukh.o@nltu.edu.ua

Загвойська Людмила Дмитрівна, канд. екон. наук, доцент, кафедра екологічної економіки.

Email: lyudmyla.zahvoyska@nltu.edu.ua; https://orcid.org/0000-0002-0028-4723

цитування за Дсту: Пелюх О. Р., Загвойська Л. Д. Дослідження уподобань населення львівщини щодо рекреаційних лісів методом експерименту з вибором. Науковий вісник НЛтУ України. Серія Економічна. 2018, т. 28, № 9. С. 73-80

Citation APA: Pelyukh, O. R., \& Zahvoyska, L. D. (2018). Investigation of Lviv region population's preferences regarding recreational forests using choice experiment method. Scientific Bulletin of UNFU, 28(9), 73-80. https://doi.org/10.15421/40280915

Науковий вісник НЛтУ України, 2018, т. 28, № 9 Scientific Bulletin of UNFU, 2018, vol. 28, no 9 
лісового менеджменту.

Розвиток рекреації та природоорієнтованого туризму важливі для Карпатського регіону, оскільки сприяють підвищенню рівня зайнятості і диверсифікації його економіки, збереженню і розвитку культурного потенціалу і природного капіталу, а також підвищують рівень екологічної спрямованості інновацій національної економіки, сприяють гармонізації відносин між різними країнами та народами (Resolution, 2017).

Для закриття інноваційно-практичного розриву і посилення конкурентоспроможності в умовах зміни клімату, багатоцільовий менеджмент лісів потребує знань про уподобання і переваги суспільства, зокрема щодо рекреаційних лісів (Hörnsten \& Fredman, 2000; Kang, 2010). Такі дослідження, проведені в європейських країнах і США, підказують усталені уподобання рекреантів (Giergiczny et al., 2015; Filyushkina et al., 2017 etc.), хоча й застерігають щодо важливості природного, соціального і культурного контекстів, які впливають на ці уподобання (Nielsen et al., 2007). В Україні теж маємо низку досліджень уподобань щодо ПЛЕ, зокрема (Blushchak \& Soloviy, 2009; Kalutskiy, 2012; Zahvoyska \& Bas, 2007; Nijnik et al., 2017), однак вони проводилися без уваги до характеристик лісів, врахування яких важливе для прийняття рішень на засадах сталого ведення лісового господарства, зокрема - переформування похідних ялинових деревостанів (Pelyukh, 2018).

Із проведених на сьогодні досліджень відомо, що візуальна різноманітність лісів, зокрема видова і вікова структури, повнота, наявність підліску, зімкнутість крон і наявність відмерлої деревини визначають рекреаційну цінність лісів. Автори (Gundersen \& Frivold, 2008), аналізуючи результати 53 досліджень уподобань жителів Фінляндії, Швеції та Норвегії щодо лісових ландшафтів, виявили, що визначальними характеристиками $є$ розмір дерев: їхній діаметр і висота. У роботі (Edwards et al., 2012), досліджуючи громадську думку щодо характеристик лісів на прикладі чотирьох європейських регіонів - скандинавського та центральноєвропейського, а також в Іспанії та Великобританії, виявили, що з дванадцяти запропонованих респондентам характеристик лісів найважливішим для вибору місця відпочинку виявився розмір дерев, а отже вік деревостану: респонденти полюбляють старші ліси з більшими деревами. Автори (Nielsen et al., 2007; Filyushkina et al., 2017) уточнюють, що респонденти віддають перевагу різновіковим лісам порівняно з одновіковими.

Повнота лісу теж впливає на його рекреаційну привабливість. Зокрема, низькоповнотний ліс, в якому відсутній різноманітний видовий склад, і ліс із високою повнотою, який важко охопити поглядом - мають низьку рекреаційну цінність для респондентів. Це підтверджують результати роботи (Ribe, 1989), який вважає, що низьку рекреаційну привабливість молодих лісів можна пояснити їхньою високою повнотою.

Дослідження уподобань рекреантів щодо певних деревних порід, проведені в різних культурних і екологічних контекстах, показали гетерогенність досліджуваних уподобань. Спільним для всіх досліджень $є$ висновок про те, що рекреанти віддають перевагу мішаним лісам. Однак дослідження, здійснені в Данії, Великобританії і Швеції (Filyushkina et al., 2017), показали, що респонденти віддають перевагу мішаним лісам порівняно 3 листяними; і листяним порівняно 3 хвойними, тоді як фіни (Tyrvainen et al., 2003) та деякі інші народи (Каlutskiy, 2012) полюбляють хвойні.

Дослідження уподобань мешканців Данії, яке здійснив (Jensen, 1999), показало, що данці віддають перевагу старшим мішаним лісам. Результати дослідження, проведеного у Польщі (Giergiczny et al., 2015), теж засвідчують, що респонденти полюбляють відвідувати стиглі мішані різновікові ліси з багатою вертикальною структурою та нерівномірним розміщенням дерев на ділянці. Встановлено, що кількість видів дерев позитивно корелює з рекреаційною цінністю лісу. Дослідники також зазначають, що респонденти позитивно оцінюють наявність туристичної інфраструктури.

Наявність у лісі відмерлої та пошкодженої деревини неоднозначно впливає на вибір респондентами цього лісу для відпочинку (Tyrvainen et al., 2003). Одні pecпонденти розглядають іiі наявність як ознаку нераціонального використання лісових ресурсів, недбалість лісівників чи пошкодження деревостану. Проте молоді, добре освічені та стурбовані екологічними проблемами люди, прихильніше ставляться до наявності відмерлої деревини. (Nielsen et al., 2007) зазначають, що данці сприймають декілька відмерлих чи всихаючих дерев у лісі як ознаку більш природного лісу.

Лісовий менеджмент відіграє ключову роль у формуванні лісів із відповідними характеристиками, а отже, впливає на їхню рекреаційну иінність. Досліджуючи цей вплив менеджменту на прикладі Данї (Nielsen et al., 2007) виявили, що респонденти готові платити більше за перехід до ведення наближеного до природи лісівництва. Ці результати дослідження підтверджують (Norden et al., 2017), які виявили, що лісовласники та менеджери лісового господарства у Швеції високо оцінюють і практикують створення великої різноманітності деревних порід у лісі, оскільки вони краще захищають місцевість від природних катаклізмів і шкідників.

В Україні теж здійснюють дослідження щодо сприйняття населенням ПЛЕ, однак у цих дослідженнях ліси розглядають як узагальнене поняття, без уваги до зазначених вище характеристик, таких як порода дерев, вік, повнота, наявність / відсутність підліску, зімкнутість крон, умов відпочинку та ін. Зокрема, в дослідженнях (Kopach \& Zahvoyska, 2006; Zahvoyska \& Shvediuk, 2016) аналізують готовність платити за збереження лісів в інтересах майбутніх поколінь, а дослідження (FLEG, 2014; Lutsiv, 2015; Zahvoyska \& Bas, 2007) більше зосереджуються на вигодах, які населення отримують від лісових екосистем загалом, без уточнення характеристик цих лісів.

Економічну вартість окремих функцій / ПЛЕ оцінювали чимало науковців, зокрема водоохоронну функцію оцінювали (Vrublevska \& Kulchytsky-Zhyhailo, 2007), грунтозахисну - (Vrublevska \& Sakal, 2007), киснепродукувальну - (Melnyk, 2016), функцію поглинання вуглецю - (Soloviy \& Ilkiv, 2011) та ін. Порівняння вигід від похідних ялинників і мішаних ялиново-букових лісів можемо знайти в працях (Krynytsky \& Chernyvskyy, 2014; Zahvoyska et al., 2017). Однак наведені в них оцінки мають якісний характер, тоді як формування менеджменту лісів на принципах сталості та парадигми екосистемних послуг потребують саме грошових оцінок для підтримання стійкості лісів в умовах посилення антропогенного навантаження та зміни клімату (Soloviy, 
2007; Pelyukh \& Zahvoyska, 2017; Zahvoyska et al., 2017).

Матеріал і методи дослідження. Ідентифікація вподобань населення щзодо різних характеристик лісів необхідна для інтеграції рекреаційних інтересів суспільства у лісову політику та практику прийняття управлінських рішень в умовах розладнання похідних ялинових деревостанів, зменшення їхнього сировинного та збілышення рекреаційного використання. Тому, об'єктом цього дослідження є вподобання населення Львівщини щодо характеристик рекреаційних лісів. Предметом дослідження є теоретико-методичні підходи до ідентифікації уподобань щодо рекреаційних лісів.

Мета роботи - дослідити вподобання населення Львівщини щодо характеристик рекреаційних лісів, визначити граничну величину готовності платити (willingness to pay) та готовності подолати відстань (willingness to travel) для відвідування лісу, який відповідає уподобанням респондентів.

Методика дослідження. В економічній літературі напрацьовано чимало методів для оцінювання вартості суспільних благ (Bateman, 1999; Hanley et al., 2001; Наines-Young \& Potschin, 2009). Для дослідження вподобань населення Львівщини щодо характеристик лісів, які обирають для відпочинку, використали різновид методу висловлених переваг - метод експерименту з вибором (choice experiment), теоретичні положення якого описали (Adamowich et al., 1998; Bateman, 1999) та ін. Цей метод розробили і спочатку використовували в маркетингових дослідженнях (Louviere et al., 2000), а віднедавна економісти-енвайроменталісти застосовують його для оцінки неринкових вигід, які продукують екосистеми, зокрема лісові (Hanley et al., 2001; Pelyukh \& Zahvoyska, 2017).

3 огляду на категоріальний характер залежної змінної для дослідження уподобань використовують методи моделювання дискретного вибору. Їх теоретичним підгрунтям слугують імовірнісна теорія максимізації корисності Д. Макфаддена (random utility maximisation) (McFadden, 1973), згідно з якою люди обирають альтернативу з найбільшою очікуваною корисністю, а також "характеристична" теорія попиту К. Ланкастера (Lancaster, 1966), в якій корисність товару можна описати як вектор характеристик, тож вартість товару дорівнює сумі вартостей його характеристик.

Щоб оминути методологічні обмеження лінійних моделей, використали дві моделі дискретного вибору: багатофакторні регресійні логіт (multinomial logit model) і пробіт моделі (multinomial logit probit), які відрізняються специфікацією випадкового члена: у пробіт моделі його описують стандартним нормальним розподілом $N(0 ; 1)$, а в логіт моделях - спеціальним логістичним розподілом, який наближено можна описати як $N\left(0 ; 1,6^{2}\right)$ (Borzyh \& Demeshev, 2015). Панельна специфікація змінних у цих моделях дає змогу врахувати неоднорідність уподобань завдяки розгляду декількох незалежних змінних. 3 огляду на нелінійність залежної змінної, параметри регресії використовують для визначення відносної сили впливу - граничної норми заміщення для двох характеристик, наприклад, готовності платити чи подолати додаткову відстань, які визначають як відношення відповідних параметрів моделі до параметра ціни або відстані

$$
W T T=\frac{\beta x i}{-\beta \text { distance }},
$$

де: $W T T$ - гранична готовність подолати відстань; $\beta x i-$ параметри, які оцінюють методами регресійного аналізу; $\beta$ distance - параметр відстані.

Метод експерименту з вибором досліджує висловлену поведінку респондентів в умовах гіпотетичного ринку, конкретизованого набором альтернатив для визначення вартості товарів і послуг загалом, або їхніх окремих характеристик. Респонденту пропонують обрати найкращу з переліку альтернатив, які відрізняються характеристиками та їхніми величинами (рівнями). Однією 3 альтернатив завжди є "Статус кво", або "Не вибираю жодної". Її включають до кожного набору альтернатив, оскільки хоча б одна 3 альтернатив повинна бути прийнятною для респондента (Adamowich et al., 1998; Bateman, 1999).

Оцінювання висловлених уподобань виконано з використанням прикладного програмного забезпечення BIOGEME 1.8 (Bierlaire, 2009). Для оцінювання статистичної значимості моделей використано такі критерії: перевірка відношенням правдоподібності (Likelihood ratio test), псевдо-R2 (Pseudo-R2) і скоригований псевдоR2 (Adjusted pseudo-R2).

Результати дослідження. Дослідження складалося зі семи етапів (Adamowich et al., 1998; Pelyukh \& Zahvoyska, 2017):

1. Характеристика досліджуваної проблеми. Львівська обл. належить до одного із найбільш лісистих регіонів України. Ліси займають 31,8 \% території Львівщини, тоді як у середньому по Україні цей показник становить $15,7 \%$. У лісогосподарській практиці Львівщини, як у всіх Українських Карпатах, тривалий період ігнорували багатофункціональність лісів, різноманіття ПЛЕ. Натомість акцент ставили на деревних ресурсах. Економічні інтереси, прагнення до отримання якнайбільшої вигоди вже в короткотерміновій перспективі спонукало до масштабних кількісних і якісних змін у видовому та віковому складі лісів (Pelyukh, 2018). Відтак продуктивні в минулому монокультури ялини європейської (Picea abies L. Karst), створені на місці корінних широколистяних і мішаних лісів, сьогодні, під посиленим впливом антропогенного навантаження та зміни клімату, масово всихають. Масштабна коніферизація - 27,9 тис. га на території Львівської обл. (Slobodiyan, 2012) - призвела до втрати життєздатності лісонасаджень, а відтак до зменшення їхньої продуктивності, зниження захисної функції лісових екосистем, збіднення біологічного, фітоценотичного різноманіття та рекреаційної цінності (Hensiruk, 1992; Debrynuk, 2011; Stoyko, 2012; Krynytskyy \& Chernyavskyy, 2014), погіршення добробуту місцевого населення (Soloviy \& Melnykovych, 2014), зниження рівня продукування середовищетвірних функцій, збідніння ПЛЕ. Такі наслідки породжують екологічно небезпечні процеси (повені, вітровали, карстові явища, зсуви грунту, снігові лавини тощо), які мають тенденцію до періодичної повторюваності та поступового наростання масштабів (Hensiruk, 1992; Krynytskyy \& Tretyak, 2003).

Процеси виснаження лісових екосистем Українських Карпат в умовах безпрецедентного екзистенційного виклику для людства набувають особливої актуальності. Сьогодні вкрай необхідна зміна поглядів на ліс як на 
невичерпний самовідновлювальний ресурс (Krynytskyy \& Tretyak, 2003; Henyk, 2011), перехід до управління лісами в рамках екосистемної парадигми, що відображає триєдину економічну, екологічну і соціальну природу цього феномену, посилення рекреаційного використання лісів, а відтак необхідність формування рекреаційно привабливих лісових ландшафтів. Для цього необхідно визначити яким саме характеристикам лісів віддає перевагу населення.

2. Визначення характеристик лісів та їхніх рівнів. Аналіз літературних джерел (Tyrvainen et al., 2003; Nielsen, 2007; Gundersen \& Frivold, 2008; Edwards et al., 2012; Giergiczny, 2015; Filyushkina, 2017 etc.) показав, що найбільший вплив на рекреаційну привабливість лісів чинять: видова і вікова структури, повнота, наявність / відсутність підліску, зімкнутість дерев та ін. Зважаючи на цей досвід, група науковців у складі M. Giergiczny (Університет Варшави), J. B. Jacobsen, F. Taye, A. Filuyskhina, T. Lundhede та N. Strange (Університет Копенгагена) (see Acknowledgment) обрали сім основних характеристик лісу і визначили їхні рівні (табл. 1).

Наведені характеристики лісів, відібрані на основі вивчення літератури та проведених емпіричних досліджень, представляють усі структурні характеристики лісів, які можуть бути важливими для вибору респон- дентами лісу для відпочинку. Урахування цієї інформації також важливе для менеджерів лісового господарства для формування рекреаційно-привабливих лісів.

Табл. 1. Характеристики лісів та їхні рівні

\begin{tabular}{|c|c|}
\hline Характеристика лісу & Рівень характеристики \\
\hline Відстань до лісу, км & Статус кво, 1, 5, 9, 13, 17, 21 \\
\hline Видовий склад лісів & $\begin{array}{c}\text { Статус кво, шпильковий, } \\
\text { широколистяний, мішаний }\end{array}$ \\
\hline $\begin{array}{c}\text { Висота найвищих } \\
\text { дерев у лісі, м }\end{array}$ & Статус кво, 2, 10, 25 \\
\hline $\begin{array}{c}\text { Вікова структура } \\
\text { лісів }\end{array}$ & Статус кво, одного віку, двовіковий, \\
різновіковий \\
\hline $\begin{array}{c}\text { Розмір відмерлих } \\
\text { дерев у лісі }\end{array}$ & $\begin{array}{c}\text { Статус кво, відмерлі дерева середньо- } \\
\text { го розміру, відмерлі дерева великого } \\
\text { розміру, немає відмерлих дерев }\end{array}$ \\
\hline $\begin{array}{c}\text { Пристосування для } \\
\text { пікніка }\end{array}$ & Статус кво, присутні, відсутні \\
\hline $\begin{array}{c}\text { Інформаційно-освітні } \\
\text { стенди }\end{array}$ & Статус кво, присутні, відсутні \\
\hline
\end{tabular}

3. Розроблення дизайну альтернатив. Використовуючи масив процедур і макросів (Kuhfeld, 2004), які дають змогу урахувати ортогональність, балансування характеристик та мінімізувати перекриття їхніх рівнів, розроблено 48 альтернатив або 24 комплекти вибору, в яких кожне поєднання характеристик трапляється лише один раз. Кожний комплект вибору включав три альтернативи, одна 3 яких - статус кво (рисунок).

Який з цих двох лісів Ви хотіли б відвідати, якщо такі є?
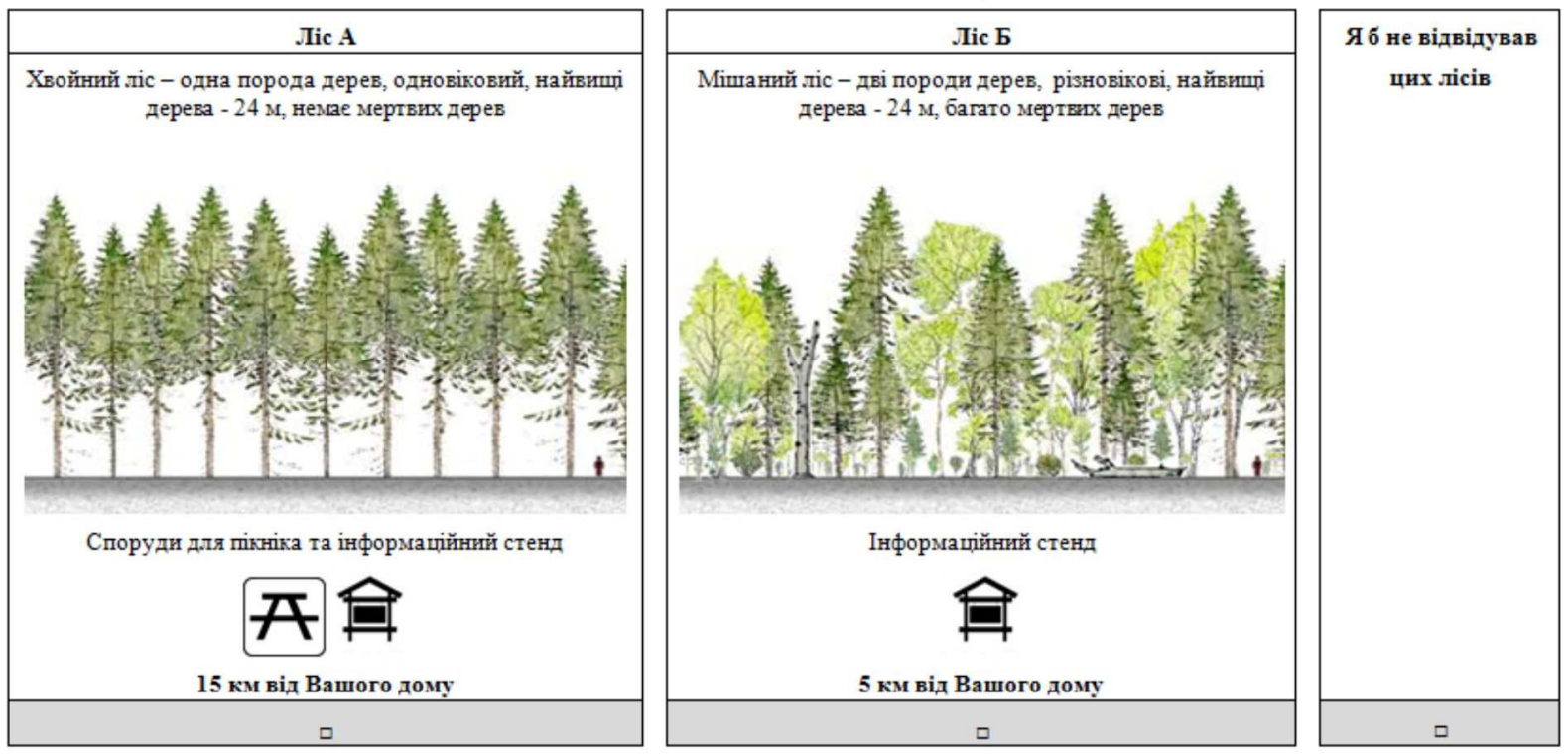

Рисунок. Приклад оформлення комплекту вибору альтернатив

Щоб зменшити когнітивне навантаження на респондентів, відповідно до рекомендацій (Adamowicz et al., 1998; Bateman et al., 2002), 24 комплекти вибору розділені на два окремих блоки з 12 комплектів. Такий дизайн забезпечив додаткову можливість для перевірки усталеності уподобань (preference stability).

4. Розроблення анкети дослідження. Для проведення дослідження використали ілюстровану анкету, яку розробила зазначена вище група науковців (see Acknowledgment). Анкета складалася 3 п'яти блоків запитань. Перший іiї блок містив 8 запитань щодо відвідування респондентами лісів упродовж останніх 12 місяців. Другий блок містив 12 ілюстрованих комплектів вибору однієї 3 трьох запропонованих альтернатив. Третій блок містив короткі запитання, які стосувались уподобання респондентами певних характеристик лісів. Відповіді на ці запитання було використано для контро- лю узгодженості уподобань, висловлених у другому блоці запитань. Окрім цього, до третього блоку розробники включили запитання, які дають респонденту можливості оцінити якість ілюстрацій комплектів вибору. Четвертий блок містив чотири запитання, які торкалися відвідування респондентами лісу в дитинстві (до 11 років) та їхніх спогадів. П'ятий блок запитань було розроблено для отримання інформації про самого респондента. Він складався зі семи запитань щодо його соціально-економічного статусу. Усі запитання були короткими, простими і реалістичними, що давало змогу мінімізувати час для заповнення анкети і мотивувало респондентів відповідати на ці запитання.

5. Визначення розміру вибірки респондентів i збір даних. Дослідження проводили шляхом прямого опитування 13-14 серпня 2015 р. У дослідженні взяли участь 100 осіб - жителі Львова та Львівської обл. - в 
основному Пустомитівського, Городоцького, Миколаївського, Стрийського, Сколівського, Славського, Бродівського районів.

Серед респондентів 48 жінок і 52 чоловіки. Їхній середньорічний дохід становив 54-72 тис. грн/рік. $20 \%$ опитаних мали вік 20-24 роки, 40\%- 25-39 років і $40 \%$ - 40 років і більше. $62 \%$ респондентів проживало в містах з населенням від 20 до 100 тис. осіб, решта - в містах із населенням понад 100 тис. осіб. Більша частина (74\%) респондентів мала вищу освіту. $69 \%$ респондентів мали дітей.

6. Оцінка результатів моделювання. Усі респонденти впродовж останніх двох місяців хоча б один раз відвідували ліс. 20 \% - відвідували двічі, 80 \% - більш ніж двічі. В середньому респонденти були в лісі 4 рази на рік. Більшість респондентів (55 \%) використовували автомобіль для відвідування лісу, громадський транспорт - $29 \%$ респондентів, велосипед - $10 \%$, і лише $6 \%$ респондентів ходили до лісу пішки. $70 \%$ респондентів гуляли в лісі упродовж останніх 12 місяців. Інші респонденти, в основному, грали 3 дітьми (67\%), зби- рали дикорослі ягоди, гриби, рослини (55\%), їздили на велосипеді чи квадроциклі (36 \%), працювали (24 \%) чи насолоджувалися лісовими краєвидами (22 \%).

Результати дослідження вподобань населення Львівщини щодо характеристик рекреаційних лісів, отримані методом найбільшої правдоподібності, представлено у вигляді коефіцієнтів логіт і пробіт моделей (табл. 2). Оцінювання якості моделей відбувалося у два етапи: спочатку оцінювали статистичну значущість моделей, а відтак - їхні параметрів.

Розрахункові значення відношення правдоподібності для обох моделей $(939,281$ та 1018,201$)$ показують, що моделі є статистично значущими з рівнем імовірності $99 \%$ (критичне значення згідно з розподілом Пірсона $\left.\chi^{2}{ }_{m=7 ;} \boldsymbol{\alpha = 0 , 0 1}=18,5\right)$. Псевдо- $\boldsymbol{R}^{2}(0,356$ та 0,386$)$ теж дає хороші результати для цих моделей: відповідно до (Louviere et al., 2000), значення скоригованого псевдо$\boldsymbol{R}^{2}$ повинно бути вищим ніж 0,1 , щоб модель можна було вважати статистично значущою, тоді як значення в межах 0,2-0,4 вважається дуже хорошим.

Табл. 2. Оцінки параметрів багатофакторних регресійних моделей уподобань населення Львівщини щодо характеристик рекреаційних лісів

\begin{tabular}{|c|c|c|c|c|}
\hline \multirow[b]{2}{*}{ Характеристика лісу } & \multicolumn{2}{|l|}{ Логіт модель } & \multicolumn{2}{|c|}{ Пробіт модель } \\
\hline & $\begin{array}{c}\text { Коефіцієнт (стандартна } \\
\text { похибка) }\end{array}$ & $t$-критерій & $\begin{array}{c}\text { Коефіцієнт (Стандартна } \\
\text { похибка) }\end{array}$ & $t$-критерій \\
\hline Відстань до лісу & $-0,023(0,004)$ & $-5,01$ & $-0,033(0,009)$ & $-3,90$ \\
\hline Видовий склад лісів & $0,228(0,030)$ & 7,59 & $0,322(0,044)$ & 7,24 \\
\hline Висота найвищих дерев у лісі & $0,010(0,003)$ & 2,78 & $0,013(0,005)$ & 2,86 \\
\hline Вікова структура лісів & $0,247(0,038)$ & 6,36 & $0,329(0,064)$ & 5,15 \\
\hline Розмір відмерлих дерев у лісі & $-0,164(0,063)$ & $-2,61$ & $-0,233(0,104)$ & $-2,25$ \\
\hline Пристосування для пікніка & $0,110(0,032)$ & 3,43 & $0,156(0,051)$ & 3,03 \\
\hline Інформаційно-освітні стенди & $0,243(0,062)$ & 3,89 & $0,407(0,087)$ & 4,66 \\
\hline Кількість респондентів & \multicolumn{4}{|c|}{100} \\
\hline Кількість заповнених комплектів вибору & \multicolumn{4}{|c|}{1200} \\
\hline Відношення правдоподібності & \multirow{2}{*}{\multicolumn{2}{|c|}{$\begin{array}{c}939,281 \\
0,356\end{array}$}} & \multicolumn{2}{|l|}{1018,201} \\
\hline Псевдо-R2 & & & \multirow{2}{*}{\multicolumn{2}{|c|}{$\begin{array}{l}0,500 \\
0,374\end{array}$}} \\
\hline Скоригований псевдо-R2 & \multicolumn{2}{|l|}{$\begin{array}{l}0,356 \\
0,349\end{array}$} & & \\
\hline
\end{tabular}

Табл. 3. Граничне значення готовності респондентів подолати відстань і платити за відвідування лісу з обраними характеристиками *

\begin{tabular}{|c|c|c|c|c|}
\hline \multirow[t]{2}{*}{ Характеристика лісу } & \multicolumn{2}{|c|}{$\begin{array}{c}\text { Готовність подолати відстань для } \\
\text { відвідування лісу з обраними } \\
\text { характеристиками, км } \\
\end{array}$} & \multicolumn{2}{|c|}{$\begin{array}{c}\text { Готовність платити за відвідування лісу } \\
\text { з обраними характеристиками, } \\
\text { грн/особу** }\end{array}$} \\
\hline & Логіт модель & Пробіт модель & Логіт модель & Пробіт модель \\
\hline Вікова структура лісів & 10,74 & 9,97 & 83,77 & 77,77 \\
\hline Інформаційно-освітні стенди & 10,57 & 12,33 & 82,45 & 96,17 \\
\hline Видовий склад лісів & 9,91 & 9,76 & 77,30 & 76,13 \\
\hline Розмір відмерлих дерев у лісі & $-7,13$ & $-7,06$ & $-68,30$ & $55,07-$ \\
\hline Пристосування для пікніка & 4,78 & 4,73 & 37,28 & 36,89 \\
\hline Висота найвищих дерев у лісі & 0,43 & 0,39 & 3,35 & 3,04 \\
\hline
\end{tabular}

Примітка: * Рівень надійності 95 \%; ** З урахуванням вартості 7,80 грн/км. Ціни 2015 р.

Табличне значення $t$-критерію Ст'юдента 3 числом ступенів свободи $n-2=100-2=98$ та довірчою імовірністю 0,95 становить $\boldsymbol{t}_{98 ; 0,05}=1,98$. Порівнюючи фактичні значення $t$-критерію Ст'юдента 3 табличним, можна зробити висновок, що всі оцінені характеристики лісів мають статистично значущі оцінки параметрів регресії. Окрім відстані та наявності відмерлої деревини в лісі, всі оцінки параметрів регресії мають позитивні значення, відтак позитивно впливають на рекреаційну цінність лісів.

Відповідно до результатів опитування, $63 \%$ респондентів оцінили наявність і розмір відмерлої деревини в лісі як дуже важливу характеристику. Водночас оцінка коефіцієнта регресії для цієї характеристики $\epsilon$ від'ємною (-0,164 і -0,233 для логіт і пробіт моделей відповідно), що свідчить про чітко виражене негативне ставлення респондентів до відпочинку в лісі, в якому є відмерла деревина. Таке сприйняття відмерлої деревини бачимо в дослідженнях (Tyrvainen et al., 2003), однак (Nielsen et al., 2007) повідомляють про схильне ставлення респондентів до їі наявності в лісі, особливо у випадках поінформованості респондентів про їі роль у збереженні біорізноманіття.

Як і очікувалось, в обох моделях оцінка коефіцієнта регресії для змінної "Відстань до лісу" є від'ємною (0,023 i -0,033), тобто респонденти бажають, щоб ліс із обраними характеристиками розташовувався якнайближче до місця їхнього проживання. Аналіз відповідей респондентів на запитання третього блоку анкети показав, що вони готові витрачати 46 хв на поїздку від місця свого проживання до лісу з обраними характеристиками, а також платити в середньому 7,80 грн за кожний наступний кілометр подорожі. 
Враховуючи отримані значення оцінок коефіцієнтів регресії для аналізованих характеристик лісів, у табл. 3 для кожної характеристики подаємо параметри функції корисності (граничної готовності подолати відстань і платити за відвідування лісу з обраними характеристиками). Гранична норма заміщення між двома характеристиками відображає граничну готовність платити, коли знаменником у співвідношенні оцінок регресійних коефіцієнтів виступає ціна, і готовність подолати додаткову відстань від місця проживання до лісу з обраними характеристиками, коли знаменником виступає відстань. У представленому дослідженні замість ціни використано відстань до лісу.

За результатами оцінювання логіт моделі респонденти готові подолати додаткові 10,74 км, щоб відвідати різновіковий ліс $(9,97$ км за пробіт моделлю) і додаткові 9,91 $(9,76)$ км - мішаний. Наявність у рекреаційних зонах лісів інформаційно-освітніх стендів спонукає населення подолати додаткові 10,57 $(12,33)$ км, тоді як наявність споруд для пікніка - лише 4,78 $(4,73)$ км. Респонденти висловили негативну готовність подорожувати та платити за відвідування лісу, де присутня відмерла деревина.

При цьому частка респондентів, які планують відвідати ліс 3 обраними характеристиками автомобілем, практично не змінюється - 56 \%, поїздом і автобусом $34 \%$ (збільшилась на $5 \%$ ), велосипедом - $7 \%$ (зменшилась на $3 \%$ ) і лише $3 \%$ респондентів (зменшилась на 3 \%) планують наступну мандрівку до лісу пішки.

Відповідно до результатів дослідження, населення Львівщини віддає перевагу різновіковим мішаним лісам, у рекреаційних зонах яких $\epsilon$ інформаційно-освітні стенди. Гранична готовність респондентів платити за відвідування лісу з такими характеристиками становить 83,77 грн, 77,30 грн та 82,45 грн - за оцінками логіт моделі, а за оцінками пробіт моделі - 77,77 грн, 76,13 грн та 96,17 грн відповідно.

7. Застосування результатів дослідження. Інтегрування отриманих результатів дослідження в лісовий менеджмент сприятиме формуванню рекреаційно привабливих лісів, підвищенню їхньої стійкості. Окрім цього, екстраполяція результатів дослідження на державному рівні важлива для вдосконалення лісової політики в сучасних умовах - відповідно до зміни попиту на ПЛЕ та умов їх формування. Зокрема, на прикладі переформування похідних ялинових деревостанів лісогосподарські підприємства можуть отримати додаткові доходи від підвищення рекреаційної цінності лісів, що важливо в умовах млявого економічного зростання країни.

Висновки. Проведене дослідження допоможе менеджерам лісового господарства зрозуміти уподобання населення щодо рекреаційно привабливих лісів, а отже, краще задовольняли соціальні та рекреаційні потреби населення поруч із потребами в деревині. З'ясовано, що населення Львівщини віддає перевагу мішаним різновіковим лісам, у рекреаційних зонах яких $є$ інформаційно-освітні стенди. Такі висновки відповідають результатам досліджень, проведених в інших країнах (Tyrvainen et al., 2003; Nielsen et al., 2007; Giergiczny et al., 2015; Filyushkina et al., 2017). Респонденти не готові відвідувати ліси, які розташовані далеко від їхнього місця проживання та в яких є відмерла деревина великого розміру. Такі результати можна пояснити поширеними на території Львівщини процесами всихання яли- нових і соснових лісів, які негативно впливають на їхню рекреаційну цінність. Цю особливість лісового господарства області потрібно враховувати під час екстраполяції отриманих результатів на державному рівні та під час розроблення лісової політики.

Результати цього дослідження роблять позитивний вклад у поточні дискусії щодо необхідності й економічної ефективності переходу до наближеного до природи лісівництва на території Львівської обл., підтверджуючи важливість цього заходу підвищенням рекреаційної цінності різновікових мішаних лісів.

\section{Acknowledgements}

This article is based upon the research conducted within a context of the Cost Action FP1206 European mixed forests. Integrating Scientific Knowledge in Sustainable Forest Management coordinated by Dr. Andres Bravo-Oviedo (Vice Chair: Prof. Hans Pretzsch). We would also like to thank Prof. Jette Bredahl Jacobsen for her supervision of this study, to a team who worked on the questionnaire development: Marek Giergiczny (University of Warsaw, Poland), Fitalew Taye, Anna Filuyskhina, Thomas Lundhede and Niels Strange (University of Copenhagen, Denmark) and all those who took part in the questionnaire.

\section{Перелік використаних джерел}

Adamowicz, W. L., Boxall, P., Williams, M. \& Louviere, J. (1998). Stated Preference Approaches for Measuring Passive Use Values: Choice Experiments and Contingent Valuation. American Journal of Agricultural Economics, 80(1), 64-75. Retrieved from: https://doi.org/10.2307/3180269

Bateman, I., Carson, R., Day, B., Hanemann, M., Hanley, N., Hett, T., Jones- Lee, M., Loomes, G., Mourato, S., Ozdemiroglu, E., Pearce, D. W., Sugden, R., \& Swanson, J. (2002). Economic valuation with stated preference techniques: A manual. Edward Elgar, Cheltenham, UK. https://doi.org/10.4337/9781781009727

Bierlaire, M. (2009). Estimation of discrete choice models with BIOGEME 1.8. Retrieved from: http://biogeme.epfl.ch/archives/v18/tutorialv18.pdf

Blushchak, H. M., \& Soloviy, I. P. (2009). Ecological and economic evaluation of social functions of forests within the urbanized territories. Scientific Bulletin of UNFU, 19(3), 68-73. [In Ukrainian].

Borzyh, D. A., \& Demeshev, B. B (2015). Econometics in tasks and exercises. Moscow: Lenand. [In Russian].

Budyenko, T. (2016). X on Y: how to manage Millennium generation employees. Retrieved from: http://biz.liga.net/upskill/all/stati/3298755-zachem-nuzhen-osobyy-podkhod-k-sotrudnikam-pokoleniya-millenium.htm

Debrynuk, Yu. M. (2011). Die-back of the fir forests: causes and consequences. Scientific Bulletin of UNFU, 21(16), 32-38. [In Ukrainian].

Edwards, D., Jay, M., Jensen, F. S., Lucas, B., Marzano, M., Montagne, C., Pearce, A., \& Weiss, G. (2012). Public preferences for structural attributes of forests: Towards a pan-European perspective. Forest Policy and Economics, 19, 12-19. Retrieved from: https://doi.org/10.1016/i.forpol.2011.07.006

ENPI EAST FLEG II (2014). National report on forest products dependence of rural communities in Ukraine. Retrieved from: http://www.fleg.org.ua/docs/781

FAO. (1988). Forestry policies in Europe, 86. Rome. Retrieved from: http://www.fao.org/forestry/62269/en/.

Filyushkina, A., Agimass, F., Lundhede, T., Strange, N., \& Jacobsen, J. B. (2017). Preferences for variation in forest characteristics: Does diversity between stands matter? Ecological Economics, 140, 22-29. https://doi.org/10.1016/j.ecolecon.2017.04.010

Giergiczny, M., Czajkowski, M., Żylicz, T., \& Angelstam, P. (2015). Choice experiment assessment of public preferences for forest structural attributes. Ecological Economics, 119, 8-23. https://doi.org/10.1016/j.ecolecon.2015.07.032 
Grytsyuk, M. Yu., \& Hrytsiuk, Yu. I. (2018). Nature and Sustainable Development of Tourism in the Carpathian Region Ukraine. Scientific Bulletin of UNFU, 28(2), 99-110. https://doi.org/10.15421/40280219

Gundersen, V. S., \& Frivold, L. H. (2008). Public preference for forest structures: a review of quantitative survays in Finland, Norway and Sweden. Urban Forestry \& Urban Greening, 7(4), 241-258. https://doi.org/10.1016/j.ufug.2008.05.001

Haines-Young, R., \& Potschin, M. (2009). Methodologies for defining and assessing ecosystem services. Final report to Joint Nature Conservation Committee.

Hanley, N., Mourato, S., \& Wright, R. (2001). Choice modelling approaches: a superior alternative for environmental valuation? $\mathrm{Jo}$ urnal of Economic Surveys, 15(3), 435-462 https://doi.org/10.1111/1467-6419.00145

Hensiruk, S. A. (1992). Forests of Ukraine. Kyiv: Naukova Dumka. [In Ukrainian].

Henyk, Ya. V. (2011). Causes and consequences of deforestation and degradation of forest ecosystems in Ukraine. Scientific Bulletin of UNFU, 21(16), 118-122. [In Ukrainian].

Hörnsten, L., \& Fredman, P. (2000). On the distance to recreational forests in Sweden. Landscape and urban planning, 51(1), 1-10. https://doi.org/10.1016/S0169-2046(00)00097-9

Jensen, F. S. (1999). Forest recreation in Denmark from the 1970 s to the $1990 \mathrm{~s}$. The Research Series. (Vol. 26). Danish Forest and Landscape Research Institute, Hoersholm, Denmark.

Kalutskiy, I. F. (2012). Recreation forest use in the Precarpathian region, the reserves of its development and use. Carpathian region, 2, 50-59. [In Ukrainian].

Kang, K. R. (2010). Comparative study on monetary estimates of the preservation value of recreational forests through contingent valuation methods. Journal of the Korean Institute of Landscape Architecture, 38(2), 25-36.

Kopach, N. I., \& Zahvoyska, L. D. (2006). Approaches and methods to determining the economic value of forest ecosystem services. Scientific Bulletin of UNFU, 16(7), 231-237. [In Ukrainian].

Krynytskyy, H. T., \& Chernyavskyy, M. V. (2014). Close to nature and multifunctional forest management in the Carpathian region of Ukraine and Slovakia. Uzhgorod: PE "Kolo". [In Ukrainian].

Krynytskyy, H., \& Tretyak, P. (2003). Condition of forests of the Ukrainian Carpathians Mountains, environment problems and prospects. Ecological collection. Ecological problems of the Carpathians region, 12, 54-65. [In Ukrainian].

Kuhfeld, W. (2004). Marketing Research Methods in SAS. Experimental Design, Choice, Conjoint and Graphical Techniques. SAS Institute Inc. Retrieved from: http://www.support.sas.com/technote/ts694/pdf

Lancaster, K. (1966). A new approach to consumer theory. Journal of Political Economy, 74(2), 132-157. https://doi.org/10.1086/259131

Lindhagen, A. (1996). Forest recreation in Sweden. Four case studies using quantitative and qualitative methods. Swedish University of Agricultural Sciences, Department of Environmental Forestry, Uppsala, Sweden.

Louviere, J., Hensher, D. A., \& Swait, J. (2000). Stated choice methods. analysis and applications. Cambridge University Press. https://doi.org/10.1017/CBO9780511753831.008

Lutsiv, N. G. (2015). Applying the subjective method of economic evaluation of natural recreational resources. Scientific Bulletin of UNFU, 25(7), 84-88. [In Ukrainian].

McFadden, D. (1973). Conditional logit analysis of qualitative choice behavior. In P. Z.: Frontiers in Econometrics. Academic Press Inc., New York, 105-142.

Melnyk, O. M. (2016). The evaluation of oxygen production function of forests of National Natural Park "Prypiat-Stokhid". Scientific Bulletin of UNFU, 26(5), 115-121. https://doi.org/10.15421/40260517

Nevenchenko, A. I. (2015). Ecological and recreational direction of development - a very important component of the Carpathian region tourist infrastructure optimization. Scientific Bulletin of UNFU, 25(5), 161-164. [In Ukrainian].
Nielsen, A. B., Olsen, S. B., \& Lundhede, T. (2007). An economic valuation of the recreational benefits associated with nature-based forest management practices. Landscape and Urban Planning, 80, 63-71. https://doi.org/10.1016/j.landurbplan.2006.06.003

Nijnik, A., Nijnik, M., Kopiy, S., Zahvoyska, L., Sarkki, S., Kopiy, L., \& Miller, D. (2017). Identifying and understanding attitudinal diversity on multi-functional changes in woodlands of the Ukrainian Carpathians. Climate Research, 73(1-2), 45-56. https://doi.org/10.3354/cr01448

Norden, A., Coria, J., Jonson, A. M., Lagergren, F., \& Lehsten, V. (2017). Divergence in stakeholders preferences: Evidence from a choice experiment on forest landscapes preferences in Sweden. Ecological Economics, 132, 179-195. https://doi.org/10.1016/j.ecolecon.2016.09.032

Pelyukh, O. R., \& Zahvoyska, L. D. (2017). Choice experiment method in forest ecosystem services valuation. Scientific Bulletin of UNFU, 27(7), 46-52. https://doi.org/10.15421/40270708

Pelyukh, O. R. (2018). The essence and economic-legal foundations of secondary norway spruce stands conversion process in the Ukrainian Carpathians. Scientific Bulletin of Kherson State University, 28, 36-41. [In Ukrainian].

Resolution. (2018). Resolution of the Cabinet of Ministers of Ukraine "On Approval of the Strategy for the Development of Tourism and Resorts for the period up to 2026". Retrieved from: http://www.kmu.gov.ua/control/ru/cardnpd?docid=249826501. [In Ukrainian].

Ribe, R. G. (1989). The aesthetics of forestry: what has empirical preference research taught us? Journal of Environmental Management, 13, 55-74. https://doi.org/10.1007/BF01867587

Roovers, P., Merny, M., \& Gulinck, H. (2002). Visitor profile, perceptions and expectations in forests from a gradient of increasing urbanisation in central Belgium. Landscape and Urban Planning, 59(3), 129-145. https://doi.org/10.1016/S0169-2046(02)00011-7

Slobodiyan, P. Ya. (2012). Condition of natural spruce stands Ukrainian Carpathians. Scientific Bulletin of UNFU, 22(5), 55-60. [In Ukrainian].

Soloviy, I. P. (2007). Forest policy paradigm transformation as an answer on global environmental and economic challenges of societal development. Proceedings of the Forestry Academy of Sciences of Ukraine. Collection of Research Papers, 5, 110-114. [In Ukrainian].

Soloviy, I. P., \& Ilkiv, Kh. I. (2011). Ecological and economic assessment of the carbon sequestration process in forest ecosystem of the Carpathian region. Scientific Bulletin of UNFU, 21(17), 97-103. [In Ukrainian].

Soloviy, I. P., \& Melnykovych, M. P. (2014). Contribution of forestry to wellbeing of mountain forest dependent communities' in the Ukrainian Carpathians. Proceedings of the Forestry Academy of Sciences of Ukraine. Collection of Research Papers, 12, 233-241.

Statistics. (2018). State Statistics Service of Ukraine. Retrieved from URL: http://www.ukrstat.gov.ua/. [In Ukrainian].

Stoyko, S. M. (2012). The antropogenical transformation of forests in Ukrainian Carpathians and vegetation belts as ecosystem models for renaturalization of secondary phytocoenoses. Bulletin of Life Safety $L N U, 6,196-202$. [In Ukrainian].

Tyrvainen, L., Silvennoinen, H., \& Kolehmainen, O. (2003). Ecologi$\mathrm{cal}$ and aesthetic values in urban forest management. Urban Forestry \& Urban Greening, 1(3), 135-149. https://doi.org/10.1078/1618-8667-00014

UNECE, FAO. (2011). The European Forest Sector Outlook Study II. 2010-2030. United Nations Economic Commission for Europe; Food and Agriculture Organisation, Geneva.

Vrublevska, O. V, \& Sakal, O. V. (2007). Economic evaluation of soil protective function of forests. Scientific Bulletin of UNFU, 17(8), 133-139. [In Ukrainian].

Vrublevska, O. V. (2007). Economic valuation of forest assets: casestudy for Brody region. Scientific Bulletin of UNFU, 17(5), 22-29. [In Ukrainian].

Vrublevska, O. V., \& Kulchtsky-Zhyhailo, I. Ye. (2007). Quantification and economic evaluation of the water production function of forest. Scientific Bulletin of UNFU, 17(6), 58-64. [In Ukrainian]. 
Zahvoyska, L. D., \& Bas, T. B. (2007). Preferences of L'viv region population regarding forest ecosystems services. Scientific Bulletin of UNFU, 17(7), 96-104. [In Ukrainian].

Zahvoyska, L. D., \& Pelyukh, O. R. (2016). DPSIR-model of interaction between social and ecological systems: phenomenon of spruce stands drying in Ukrainian Carpathians. Odessa National University Herald. Economy, 8(50), 82-88. [In Ukrainian].

Zahvoyska, L. D., \& Shvediuk, I. V. (2016). Cost-benefit analysis of reforestation process: Male Polissya case study. Proceedings of the Forestry Academy of Sciences of Ukraine. Collection of Research Papers, 14, 236-243. [In Ukrainian].
Zahvoyska, L. D., Pelyukh, O. R., \& Maksymiv, L. I. (2017). Methodological considerations and their application for evaluation of benefits from the conversion of even-age secondary Norway spruce stands into mixed uneven-aged woodlands with a focus on the Ukrainian Carpathians. Austrian Journal of Forest Science, 134, 251281.

Zahvoyska, L., \& Melnyk, A. (2008). Forest management modeling towards sustainable development. Bulletin of Lviv University. Economic issue, 40, 105-111. [In Ukrainian].

О.Р. Пелюх, Л. Д. Загвойская

Национальный лесотехнический университет Украины, г. Львов, Украина

\section{ИССЛЕДОВАНИЕ ПРЕДПОЧТЕНИЙ НАСЕЛЕНИЯ ЛЬВОВСКОЙ ОБЛАСТИ ОТНОСИТЕЛЬНО РЕКРЕАЦИОННЫХ ЛЕСОВ МЕТОДОМ ЭКСПЕРИМЕНТА С ВЫБОРОМ}

Рост спроса на отдых в лесах Карпат ставит перед менеджерами лесного хозяйства новые вызовы, связанные с необходимостью формирования рекреационно привлекательных лесов. В Европе в последние десятилетия проведено немало исследований относительно общественного восприятия рекреационных лесов, предпочтений относительно их характеристик. В Украине подобные исследования тоже проводились, однако в этих исследованиях леса рассматривались как обобщенное понятие. Для исследование предпочтений относительно их характеристик рекреационных лесов применен один из методов исследования высказанных преимуществ - метод эксперимента с выбором, теоретическим основанием которого служат вероятностная теория максимизации полезности Д. Макфаддена и "характеристическая" теория поведения потребителя, сформулированная К. Ланкастером. Моделирование дискретного выбора рекреантами характеристик леса для отдыха выполнено с использованием многофакторных регрессионных моделей - логит и пробит моделей - методом наибольшего правдоподобия с использованием программного обеспечения BIOGEME 1.8. По результатам анализа данных установлено, что население Львовской обл. предпочитает смешанные разновозрастные леса, в рекреационных зонах которых имеются информационно-образовательные стенды. Оценки коэффициентов регрессии для этих характеристик в обеих моделях статистически значимые, положительные и имеют высокие значения. Вместе с тем, респонденты не склонны посещать лес, который находится далеко от места их проживания, и лес, в котором есть сухостой. Определены предельные значения готовности платить и преодолеть расстояние для посещения лесов с предпочитаемыми характеристиками. Обоснована необходимость интеграции полученных результатов исследования в практику принятия управленческих решений для расширения рекреационного использования лесов, что приоритезирует формирование рекреационно привлекательных лесных ландшафтов и древостоев, устойчивых к изменениям климата и усиления антропогенных нагрузок.

Ключевые слова: рекреационные леса; характеристики лесов; метод эксперимента с выбором; предпочтения; готовность платить; готовность преодолеть расстояние; логит и пробит модели.

O. R. Pelyukh, L. D. Zahvoyska

Ukrainian National Forestry University, Lviv, Ukraine

\section{INVESTIGATION OF LVIV REGION POPULATION'S PREFERENCES REGARDING RECREATIONAL FORESTS USING CHOICE EXPERIMENT METHOD}

Growing demand for recreation in the Carpathian Mountains gives rise to new challenges related to the need for formation of recreationally attractive forests. In recent decades in Europe, many studies have been conducted on social perception of recreational forests, and preferences for their attributes. Similar studies were conducted in Ukraine, but in these studies forests were considered as a generalized concept. The purpose of this research was to investigate the Lviv region population preferences regarding recreational forest attributes and to assess the marginal willingness to pay and willingness to travel to visit a forest in accordance to the stated preferences. Lancaster's characteristics demand theory and McFadden's random utility maximization theory served as a methodological background of the research. Modeling of discrete forest recreational attributes choice is accomplished using multinomial regression models such as logit and probit models using the maximum likelihood method and BIOGEME 1.8 software. Data for the analysis were derived through face-to-face interviews with one hundred respondents using a specially designed illustrated questionnaire. We have revealed that Lviv region population prefers mixed uneven-aged forests with informational and educational stands in recreational zones. The regression coefficients of these attributes in logit and probit models are significant, positive and high. At the same time, respondents do not intend to visit forests that are far from their place of residence and forest with dead trees left in the forest stands. Necessity of integrating the obtained research results into forest decision-making for expanding the recreational use of forests and formation recreationally attractive forest landscapes and woodlands resistant to climate change and anthropogenic pressure is substantiated. The results of this research make a positive contribution to the ongoing discussions on the need of secondary Norway spruce stands conversion into mixed uneven-aged forest stands according to the close-to-nature paradigm of forest management on the territory of Lviv region.

Keywords: recreational forests; forest attributes; choice experiment method; preferences; willingness to pay; willingness to travel; logit and probit models. 